\title{
Thelytokous parthenogenesis in the damselfly Ischnura hastata (Odonata, Coenagrionidae): genetic mechanisms and lack of bacterial infection
}

\author{
MO Lorenzo-Carballa and A Cordero-Rivera \\ Departamento de Ecoloxía e Bioloxía Animal, Grupo de Ecoloxía Evolutiva e da Conservación, Universidade de Vigo, EUET Forestal, \\ Campus Universitario, Pontevedra, España, Spain
}

\begin{abstract}
Thelytokous parthenogenesis, the production of female-only offspring from unfertilized eggs, has been described in all the insect orders, but is a rare phenomenon in the Odonata (dragonflies and damselflies). The only-known case of parthenogenesis in this group is the North American damselfly species Ischnura hastata, which has parthenogenetic populations in the Azores Islands. Here, we present for the first time the results of laboratory rearing, which showed parthenogenetic reproduction in the Azorean I. hastata populations. In an attempt to understand how parthenogenesis could have evolved in this species, we first determined the genetic mode of parthenogenesis by analys-
\end{abstract}

ing the genotype of parthenogenetic females and their offspring at three polymorphic microsatellite loci. In addition, we used polymerase chain reaction amplification to test whether parthenogenesis in I. hastata could be bacterially induced. Our data indicate that thelytoky is achieved through an (at least functionally) apomictic mechanism and that parthenogenesis is not caused by endosymbionts. Finally, we discuss possible routes to parthenogenetic reproduction, as well as the evolutionary implications of this type of parthenogenesis.

Heredity (2009) 103, 377-384; doi:10.1038/hdy.2009.65; published online 10 June 2009

Keywords: parthenogenesis; thelytoky; Ischnura hastata; Odonata; microsatellites; apomixis

\section{Introduction}

Sexual reproduction is found in the majority of organisms, such that only $0.1 \%$ of animal species show some type of asexual reproduction (Suomalainen et al., 1987). This occurs despite the numerous costs associated with mating and the fact that, all else being equal, asexual females could potentially produce twice the number of daughters of sexual females, so that the proportion of asexual females/sexual females could increase exponentially in each generation (the so-called 'twofold cost of sex', Williams, 1966, 1975; Daly, 1978; Maynard-Smith, 1978; Bell, 1982). Asexual reproduction includes a variety of mechanisms, such as fission in unicellular organisms, fragmentation in colonials or parthenogenesis, which is defined as the development of a non-fertilized egg, and usually produces only female offspring (Suomalainen et al., 1987).

Parthenogenesis has been described in all of the major animal groups and it is quite frequent in rotifers, nematodes or arthropods (Bell, 1982). Among vertebrates, cases have been described in all the groups except in birds and mammals (Avise et al., 1992). The rarity of this type of reproduction has made it an intensively studied phenomenon. Early work focused on the

Correspondence: Dr MO Lorenzo-Carballa, Departamento de Ecoloxía e Bioloxía Animal, Grupo de Ecoloxía Evolutiva e da Conservación Universidade de Vigo, EUET Forestal, Campus Universitario, Pontevedra, España 36005, Spain.

E-mail: olalla.lorenzo@uvigo.es

Received 29 December 2008; revised 18 March 2009; accepted 3 May 2009; published online 10 June 2009 distribution of parthenogenetic forms (Vandel, 1928), but in the mid-1960s, emphasis in the study of the evolution of sexual reproduction caused an increase in studies, mainly theoretical, about the advantages of sexual reproduction over parthenogenetic reproduction. Thus, a number of models have been developed, which try to show the conditions under which a significant advantage of sexual reproduction exists, such that it compensates for the two-fold cost (Kondrashov, 1993; West et al., 1999).

One of the main questions is how the diploid number of chromosomes is restored in the absence of fertilization of the egg. Mechanisms of genetic restoration of diploidy have been traditionally grouped into two main types: apomixis and automixis. In apomixis, meiotic division is suppressed. As a result of the lack of chromosome pairing and subsequent reductional division, descendants are genetically identical copies of their mothers. Thus, ploidy level and heterozygosity are maintained during the entire process. Genetic variation can be generated by means of mutations, somatic crossing over, polyploidy or transposition. This type of parthenogenesis is the most common and it is found in several animal groups (Suomalainen et al., 1987).

In automixis, the first meiotic stages are similar to those observed in animals with sexual reproduction. As a result of reduction in the number of chromosomes during meiosis, haploid nuclei are formed, but diploidy is restored immediately by the fusion of two of these haploid nuclei, by the formation of a restitution nucleus or by endomitosis. Automixis can occur by, at least, seven different modes, most of which lead to complete 
homozygosis, or at least an observed increase in homozygosity (Suomalainen et al., 1987). In addition, many automictic organisms have evolved mechanisms to suppress recombination and these can be referred to as functionally apomictic organisms (Lynch, 1984).

The mode of origin of parthenogenetic populations has a strong influence on subsequent levels of genetic diversity, ecological adaptability and competitive ability with sexual relatives (Bell, 1982). Different ways have been described, in which parthenogenetic lineages may originate from sexual species (reviewed in Simon et al., 2003). The majority of the cases of parthenogenesis studied today are associated with bacterial infections. Three different microorganisms have been found associated with parthenogenesis in arthropods: Wolbachia (Stouthamer and Werren, 1993; Stouthamer et al., 1993; Werren, 1997; Arakaki et al., 2001; Weeks and Breeuwer, 2001) and Rickettsia (Hagimori et al., 2006), both members of the $\alpha$-proteobacteria group; and Cardinium, a member of the Cytophaga-Flexibacter-Bacteroides group (Zchori-Fein et al., 2001, 2004; Weeks et al., 2003; Zchori-Fein and Perlman, 2004; Provencher et al., 2005). In addition, an endosymbiont from the Verrucomicrobia group has been found associated with parthenogenesis in a nematode species (Vandekerckhove et al., 2000).

There are multiple ways in which endosymbionts may cause parthenogenesis: most of the cases of Wolbachiainduced parthenogenesis in haplodiploid Hymenoptera cause diploidization of unfertilized haploid eggs, which develop into females. This occurs through different forms of gamete duplication, which result in the production of fully homozygous progeny (Suomalainen et al., 1987; Stouthamer and Kazmer, 1994; Gottlieb et al., 2002; Pannebakker et al., 2004). However, in the Wolbachia-infected mite Bryobia praetiosa, the mechanism of parthenogenesis seems to be apomictic (Weeks and Breeuwer, 2001), and also a functionally apomictic mechanism of parthenogenesis has been recently described in a Rickettsia-infected hymenopteran (Adachi-Hagimori et al., 2008).

An alternative route to parthenogenesis in animals is the spontaneous loss of sex through mutations in the genes involved in the production of sexual forms (Simon et al., 2003), or in genes related to mating behaviour and successful egg fertilization (Carson et al., 1982). Such mutations may result in the establishment of an obligate parthenogenetic lineage, or may also initiate a lineage in which a small proportion of females has the potential for parthenogenetic reproduction, which in turn will provide for the possibility to select for parthenogenesis in the laboratory and in nature (Templeton, 1982; Kramer and Templeton, 2001). Spontaneous origins of parthenogenesis have been shown in a wide range of invertebrates, including snails, ostracods, crustaceans and insects (reviewed in Simon et al., 2003). Tychoparthenogenesis refers to the occasional, spontaneous development of eggs without fertilization in otherwise sexually reproducing species, a form of reproduction which is characterized by a low-hatching success of unfertilized eggs (White, 1973; Bell, 1982; Suomalainen et al., 1987). All known tychoparthenogens are automictic, reproducing through meiotic parthenogenesis (Bell, 1982; Suomalainen et al., 1987). Preserving meiosis is the simplest route of evolution from sexual to parthenogenetic reproduction, but as mentioned above, this mechanism usually leads to a rapid increase of the observed homozygosity over generations (White, 1973; Templeton, 1982; Suomalainen et al., 1987). However, a recent study in parthenogenetic stick insects of the genus Timema suggests that apomixis may also arise suddenly from sexual reproduction, without passing through a stage of automictic parthenogenesis (Schwander and Crespi, 2009).

Ischnura hastata is a New-World damselfly species, widely distributed in North America, the Caribbean and Galapagos islands (Dunkle, 1990). As generally known for Odonata, only bisexual populations have been described in the above regions. However, in the Azores Islands, where the species has also been described (Belle and Van Tol, 1990, Cordero Rivera et al., 2005), femaleonly, parthenogenetic populations have been found. Given that this is the only-known case of parthenogenesis described in this insect order (Cordero Rivera et al., 2005), it was of great relevance to investigate the genetic mechanism as well as the mode of origin of parthenogenesis in these populations to understand how parthenogenesis could have evolved in this insect group. In this paper, we present for the first time the results of laboratory rearing, which showed parthenogenetic reproduction in $I$. hastata from the Azores. We also investigate the genetic mechanism of parthenogenesis by genotyping offspring produced by parthenogenetic females at three microsatellite loci and analysing the segregation of maternal alleles among the offspring. Furthermore, we use polymerase chain reaction (PCR) screening to test for the presence of known parthenogenesis-inducing bacterial endosymbionts, to determine whether microorganisms could be involved in the asexual reproduction in this species.

\section{Materials and methods}

\section{Collection of animals and rearing conditions}

For establishing a laboratory colony of I. hastata from the Azores, 100 larvae were captured from Pico Island in July 2000. In July 2003, larvae were collected again not only from Pico, but also from Corvo and Terceira islands. Rearing of I. hastata in the laboratory was conducted as described in Lorenzo Carballa and Cordero Rivera (2007).

\section{Endosymbiont PCR assay}

Given that the majority of the cases of parthenogenesis studied today in insects are due to bacterial infections, and that Wolbachia has been also found in Odonata (Jeyaprakash and Hoy, 2000; Thipaksorn et al., 2003), I. hastata was tested for the presence of microorganisms in the reproductive tissue that could be the cause of parthenogenesis. Seven mature parthenogenetic I. hastata females preserved in absolute ethanol at $4{ }^{\circ} \mathrm{C}$ (named $\mathrm{H} 1$ trough H7) were dissected under sterile distilled water. The eggs and adjacent ovarian tissue were carefully extracted with sterile forceps (making sure that the gut was not broken during the dissection), and washed twice in a solution of $400 \mu \mathrm{l}$ saline ethylenediaminetetraacetic acid (EDTA) buffer (150 mM NaCl, 10 mM EDTA, pH 8.0), $10 \mu \mathrm{l}$ of $25 \%$ sodium dodecyl sulphate and $5 \mu \mathrm{l}$ of $10 \mathrm{mg} \mathrm{ml}^{-1}$ lysozyme. After washing, samples were incubated in the same solution for $1 \mathrm{~h}$ at $37^{\circ} \mathrm{C}$, with agitation. This washing protocol was designed by Reed 
and Hafner (2002) to wash away external sources of bacterial DNA. Tissue was then placed in $1.5 \mathrm{ml}$ microcentrifuge tubes along with $400 \mu \mathrm{l}$ of saline EDTA buffer and $5 \mu \mathrm{l}$ of $10 \mathrm{mg} \mathrm{ml}^{-1}$ lysozyme, crushed with sterile micropestles and incubated for $1 \mathrm{~h}$ at $37^{\circ} \mathrm{C}$. Genomic DNA was then extracted from the reproductive tissue using the NucleoSpinTissue kit (MACHEREYNAGEL, Düren, Germany), following manufacturer instructions.

Infections were investigated in each individual for five known reproductive parasites: Wolbachia, Arsenophonus, Cardinium, Spiroplasma and Microsporidia using specific primers listed in Table 1. PCR conditions were initial denaturation at $95^{\circ} \mathrm{C}$ for $3 \mathrm{~min}, 40$ cycles of denaturation $\left(30 \mathrm{~s}\right.$ at $\left.95^{\circ} \mathrm{C}\right)$, annealing $\left(45 \mathrm{~s}\right.$ at 55 or $60^{\circ} \mathrm{C}$, depending on primers) and extension $\left(45 \mathrm{~s}\right.$ at $\left.72^{\circ} \mathrm{C}\right)$, and a final extension at $72{ }^{\circ} \mathrm{C}$ for $2 \mathrm{~min}$. Furthermore, PCR screen with primers FD1 and RP2, which amplifies $\sim 1500 \mathrm{bp}$ of the $16 \mathrm{~S}$ ribosomal RNA gene of most Eubacteria (Weisburg et al., 1991), was also conducted. In this case, amplification conditions were one cycle of $3 \mathrm{~min}$ at $95^{\circ} \mathrm{C}$, followed by 35 cycles of $30 \mathrm{~s}$ at $95^{\circ} \mathrm{C}, 45 \mathrm{~s}$ at $55^{\circ} \mathrm{C}, 1 \mathrm{~min}$ at $72^{\circ} \mathrm{C}$ and one cycle of final extension at $72{ }^{\circ} \mathrm{C}$ for $5 \mathrm{~min}$.

The quality of each DNA extract was assessed by amplifying the $18 \mathrm{~S}$ rDNA of $I$. hastata using primers 18SF1 and 18SR1 (Wenseleers and Billen, 2000) under the following conditions: one cycle of $3 \mathrm{~min}$ at $94^{\circ} \mathrm{C}, 30$ cycles of $30 \mathrm{~s}$ at $94{ }^{\circ} \mathrm{C}, 1 \mathrm{~min}$ at $63^{\circ} \mathrm{C}, 2 \mathrm{~min}$ at $72^{\circ} \mathrm{C}$ and one cycle of $10 \mathrm{~min}$ at $72{ }^{\circ} \mathrm{C}$.

All PCR reactions were conducted in a Biometra TGradient thermocycler. For endosymbiont-specific primers and $18 \mathrm{~S}$ rDNA primers, reactions were performed in a final $25 \mu \mathrm{l}$ volume containing $2 \mu \mathrm{l}$ DNA, $1 \times$ KAPA2G Robust HotStart Buffer B, including $1.5 \mathrm{~mm}$
$\mathrm{MgCl}_{2}$ (KAPA BIOSYSTEMS, Cape Town, South Africa), $1 \times$ KAPAEnhancer 1 (KAPA BIOSYSTEMS), $0.2 \mathrm{mM}$ each dNTP (KAPA BIOSYSTEMS), $0.2 \mu \mathrm{M}$ of each primer and 0.5 units of KAPA2G Robust HotStart DNA Polymerase (KAPA BIOSYSTEMS).

For primers FD1 and RP2, PCR reactions were conducted in a final $50 \mu \mathrm{l}$ volume containing $2 \mu \mathrm{l}$ DNA, $1 \times$ buffer, $2 \mathrm{mM} \mathrm{MgCl}, 0.2 \mathrm{mM}$ each dNTP (KAPA BIOSYSTEMS), $0.25 \mu \mathrm{M}$ of each primer and 1 unit of KAPATaq DNA Polymerase (KAPA BIOSYSTEMS).

Positive controls (DNA from known infected hosts, see Table 1) were included in each PCR run. Negative controls containing no DNA template were included to check for contamination.

PCR products were detected after electrophoresis in $1.4 \%$ agarose gel stained with ethidium bromide.

\section{Genetic analysis of parthenogenesis}

To study the mode of parthenogenesis in I. hastata, we used microsatellites to compare the genotypes of parthenogenetic females with their offspring. Thus, if female $I$. hastata reproduce through apomictic parthenogenesis, we would expect offspring to be heterozygous at all loci in which their mothers were heterozygous. On the other hand, if the mode of parthenogenesis is automictic, we would expect a shift to homozygosity in the progeny, with a certain probability depending on the distance of the locus to the centromere. Offspring identical to their mothers support, but does not prove, an apomictic mechanism of parthenogenesis.

Eggs from five mature females were collected as described above, and once egg hatching started, 20 first-instar larvae from each female were collected and

Table 1 Primer pairs used for endosymbiont PCR screening in I. hastata

\begin{tabular}{|c|c|c|c|c|}
\hline Primer pair $\left(5^{\prime}-3^{\prime}\right)$ & Target group & Positive control & $\begin{array}{l}\text { Target gene } \\
\text { (fragment size) }\end{array}$ & $\begin{array}{c}\text { Annealing } \\
\text { temperature } \\
\left({ }^{\circ} \mathrm{C}\right)\end{array}$ \\
\hline $\begin{array}{l}\text { 63F GCCTAATACATGCAAGTCGAAC } \\
\text { TKSSsp TAGCCGTGGCTTTCTGGTAA }^{\mathrm{b}}\end{array}$ & Spiroplasma sp. & Tipula olacea & 16S rRNA $(\sim 450 \mathrm{bp})$ & 55 \\
\hline $\begin{array}{l}\text { CLOf GCGGTGTAAAATGAGCGTG }{ }^{c} \\
\text { CLOr1 ACCTMTTCTTAACTCAAGCCT }\end{array}$ & Cardinium hertigii & $\begin{array}{l}\text { Holocnemus } \\
\text { pluchei }\end{array}$ & $16 \mathrm{~S}$ rRNA $(\sim 466 \mathrm{bp})$ & 55 \\
\hline $\begin{array}{l}\text { Micro18F CACCAGGTTGATCTGCC }^{\mathrm{d}} \\
\text { Micro18R TTATGATCCTGCTAATGGTTC }^{\mathrm{d}}\end{array}$ & Microsporidia & $\begin{array}{l}\text { Gammarus } \\
\text { duebeni }\end{array}$ & $18 \mathrm{~S}$ rRNA $(\sim 1000 \mathrm{bp})$ & 55 \\
\hline $\begin{array}{l}\text { Ars23S-1 CGTTTGATGAATTCATAGTCAAA }{ }^{\mathrm{e}} \\
\text { Ars23S-2 GGTCCTCCAGTTAGTGTTACCCAAC }\end{array}$ & $\begin{array}{l}\text { Arsenophonus } \\
\text { nasoniae }\end{array}$ & $\begin{array}{l}\text { Nasonia } \\
\text { vitripennis }\end{array}$ & $23 \mathrm{~S}$ rRNA $(\sim 800 \mathrm{bp})$ & 60 \\
\hline $\begin{array}{l}\text { WspecF CATACCTATTCGAAGGGATAG } \\
\text { WspecR AGCTTCGAGTGAAACCAATTC }\end{array}$ & $\begin{array}{l}\text { Wolbachia } \\
\text { pipientis }\end{array}$ & $\begin{array}{l}\text { N. vitripennis } \\
\text { (LBII strain) }\end{array}$ & 16S rRNA $(\sim 438 \mathrm{bp})$ & 60 \\
\hline $\begin{array}{l}\text { FD1 CCGAATTCGTCGACAACAGAGTTTGATCCTGGCTCAG } \\
\text { RP2 CCCGGGATCCAAGCTTACGGCTACCTTGTTACGACTT }\end{array}$ & Most eubacteria & Any of the above & $16 \mathrm{~S}$ rRNA $(\sim 1500 \mathrm{bp})$ & 55 \\
\hline $\begin{array}{l}\text { 18SF1 TTGGAGGGCAAGTCTGGTGC } \\
\text { 18SR1 ACTTCGGCGGATCGCTAG }\end{array}$ & Arthropods & Any arthropod & $18 \mathrm{~S}$ rDNA $(\sim 555 \mathrm{bp})$ & 63 \\
\hline
\end{tabular}

${ }^{a}$ Mateos et al. (2006).

${ }^{\mathrm{b}}$ Fukatsu and Nikoh (2000).

${ }^{c}$ Weeks et al. (2003).

${ }^{\mathrm{d}}$ Baker et al. (1995).

'Thao and Baumann (2004).

${ }^{\mathrm{f}}$ Werren and Windsor (2000).

gWeisburg et al. (1991).

${ }^{\mathrm{h}}$ Wenseleers and Billen (2000). 
females and their offspring were frozen at $-80{ }^{\circ} \mathrm{C}$ until DNA extraction.

Three microsatellite loci, Ihas08, Ihas05 and Ihas13 (Lorenzo Carballa et al., 2007), were used to determine the genotype of individuals. Genomic DNA was extracted from each female and their progeny using the NucleoSpinTissue kit (MACHEREY-NAGEL), and then resuspended in $50 \mu \mathrm{l}$ of elution buffer. Amplifications were carried out in a $25-\mu \mathrm{l}$ reaction volume containing $1 \mu \mathrm{l}$ DNA, $1 \times$ buffer (BIOLINE, London, UK), $2 \mathrm{mM} \mathrm{MgCl}_{2}$ (BIOLINE), $5 \mathrm{pmol}$ of each primer, $0.1 \mathrm{mM}$ of each dNTP and 0.75U of BioTaqDNA Polymerase (BIOLINE). PCR cycling conditions were the same as described in Lorenzo Carballa et al. (2007). Amplified fluorescent fragments were visualized using an automated ABI 3700 sequencer (APPLIED BIOSYSTEMS, Foster City, CA, USA). Data collection, analysis and sizing were performed using ABI Prism Genescan software (APPLIED BIOSYSTEMS).

\section{Results}

\section{Laboratory rearing}

A total of 2035 females were obtained in nine generations from July 2000 to June 2003, and 985 females from July 2003 to December 2005 in seven generations. Not a single male was obtained during all this time, which confirms thelytokous parthenogenesis as the mode of reproduction of I. hastata in the Azores islands. The results of laboratory rearing are presented in Table 2. The number of females obtained was highly variable between lines, because we concentrated on rearing eggs from females that laid large clutches, and this depended on food availability for the adults.

\section{Detection of endosymbionts}

No evidence of bacterial infection was found in the parthenogenetic females analysed. PCR amplification of

Table 2 Sex of I. hastata offspring produced parthenogenetically in the laboratory

\begin{tabular}{lccc}
\hline \multirow{2}{*}{$\begin{array}{l}\text { Starting } \\
\text { year }\end{array}$} & Generation & \multicolumn{2}{c}{ Number of offspring } \\
\cline { 3 - 4 } & & Female & Male \\
\hline 2000 & 1st & 55 & 0 \\
& 2nd & 80 & 0 \\
& 3rd & 115 & 0 \\
& 4th & 142 & 0 \\
& 5th & 143 & 0 \\
& 6th & 412 & 0 \\
& 7th & 304 & 0 \\
& 8th & 506 & 0 \\
& 9th & 278 & 0 \\
Total & & 2035 & 0 \\
& & & \\
2003 & 1st & 27 & 0 \\
& 2nd & 117 & 0 \\
& 3rd & 253 & 0 \\
& 4th & 229 & 0 \\
& 5th & 101 & 0 \\
& 6th & 78 & 0 \\
7th & 180 & 0 \\
& & & \\
\hline
\end{tabular}

Wolbachia, Cardinium, Microsporidia, Arsenophonus and Spiroplasma yielded negative results. Amplification of the Wolbachia DNA using the long PCR procedure (Jeyaprakash and Hoy, 2000), which allows for the detection of this bacterium at low densities, also yielded negative results (data not shown). Furthermore, results of bacterial DNA amplification with primers FD1 and RP2 were also negative, which indicate that no other microorganism is present in the reproductive tissue of the parthenogenetic females. These results rule out bacterial infection as the cause of parthenogenesis in this species. The correct amplification of the positive controls indicates true lack of infection in this species and not a failure in the set-up of the PCR reactions (Figure 1).

\section{Mode of parthenogenesis}

The results of this experiment are presented in Table 3. All female parents were heterozygous for all three microsatellite loci analysed, and so all of them were informative with respect to the mechanism of parthenogenesis. Microsatellite analyses indicated that maternal genotypes passed unchanged to the offspring. Moreover, all the individuals analysed showed the same genotype for the three microsatellite loci. These results suggest that the genetic mechanism of parthenogenesis in I. hastata is apomictic. Microsatellites also indicate that the I. hastata females are diploid.

\section{Discussion}

The results of PCR amplification have excluded bacterial infection as the cause of parthenogenesis in I. hastata, which suggests that thelytoky in this species could have evolved naturally from sexual populations. Several authors have pointed out the existence of a series of 'rare events', which could lead to the establishment of parthenogenesis in natural populations of insect species (reviewed in Templeton, 1982). Tychoparthenogenesis has been described in a variety of invertebrates (Bell, 1982), and it has been extensively studied in several Drosophila species in the laboratory (summarized in Templeton, 1982). Nevertheless, little attention has been paid to the extent to which thychoparthenogenetic reproduction occurs in nature (Ball, 2002).

Artificial parthenogenesis has also been reported in the dragonfly species Stylurus annulatus and Stylurus oculatus (Kato et al., 1997; Watanabe et al., 1999) by incubating unfertilized eggs extracted from females in water. Karyotype analysis of the hatched larvae revealed that some of them were haploid, whereas others possessed the diploid number of chromosomes, which suggests that eggs were produced by normal meiosis and that the number of chromosomes was later restored by some unknown mechanism, probably automixis. Although larvae did not complete development, this example suggests that some parthenogenetic capacity could be expected in Odonata.

The genetic analysis of I. hastata females and their offspring revealed that the genotype is passed unchanged to the offspring and that heterozygosity is maintained in all cases, suggesting that the genetic mechanism of parthenogenesis in this species is apomictic. Whether this is a purely or a functionally apomictic mechanism remains to be verified, but the hypothesis of 

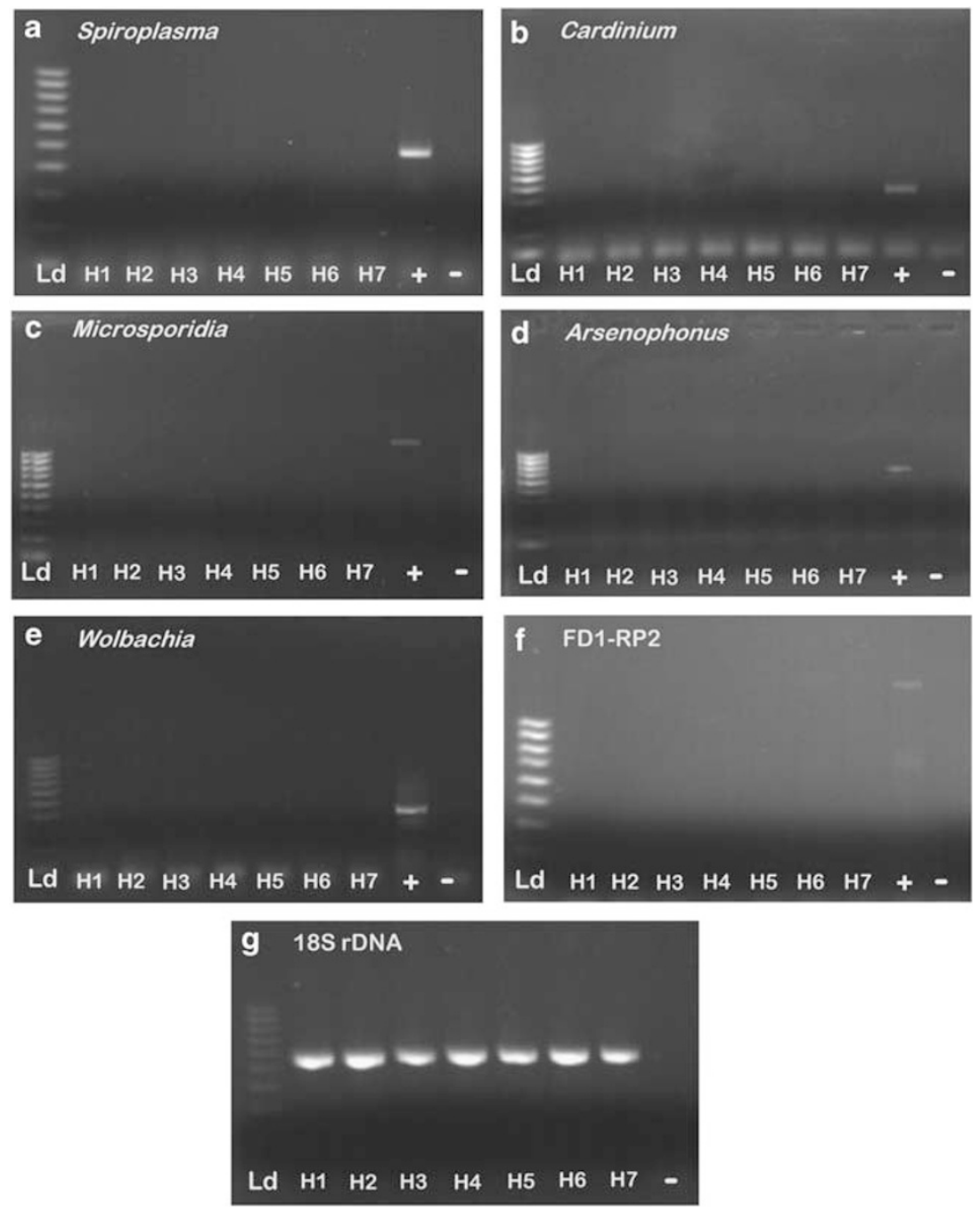

Figure 1 The results of PCR screening for endosymbionts in seven I. hastata parthenogenetic females (H1 to H7). Panels a-g show the results of the DNA amplification using the primers listed in Table 1. Ld, DNA 100 bp low ladder (SIGMA, St Louis, MO, USA); +, positive controls; - , negative PCR control (no DNA). In F, DNA from Nasonia vitripennis infected with Wolbachia was used as positive control.

an automictic mechanism seems to be more parsimonious, as automixis is the simplest route to parthenogenesis in an otherwise sexually reproducing species. In Drosophila, a genus in which parthenogenetic reproduction has been extensively studied, the mechanism of parthenogenesis is gamete duplication, which leads to complete homozygosity for almost all loci after a few generations (Templeton, 1982). However, the cases of automictic parthenogens that use homozygosity-enforcing mechanisms are rare, and in almost all known cases in which meiotic activity is observed, mechanisms such as premeiotic doubling, suppression of recombination or fusion of non-sister pronuclei insure that automixis will be functionally equivalent to apomixis, and that offspring will be, barring mutation, genetically identical to their mothers (Lynch, 1984). In premeiotic doubling, the number of chromosomes is doubled before meiosis, and this tetraploid cell undergoes normal meiosis. At the end of the meiotic division, four diploid nuclei are formed, with the same genotype of the mother. This mechanism has been described in turbellaria, lumbricids, insects, tardigrads and also in vertebrates (Suomalainen et al., 1987).
Inverted meiosis differs from normal meiosis in that the first meiotic division is equational and the second division is reductional, leading to four haploid cells. A precondition for inverted meiosis is holokinetic chromosomes, which have been described in many insect orders, such as Hemiptera, Homoptera and Lepidoptera (White, 1973). In addition, Odonata chromosomes are assumed to be holocentric (Kiauta, 1969a, b), and inverted meiosis has been suggested to occur in this insect order (Mola, 1995). In holokinetic systems with inverted meiosis, fusion of the haploid cells leads to an exact restoration of the mother's genotype. The genetic consequences of this process are thus similar to apomixis. This type of parthenogenesis is known from some insects, such as the Homoptera (Suomalainen et al., 1987).

Genetic analyses of $I$. hastata females and their offspring revealed heterozygosity for the three microsatellite loci in all five mothers and 100 daughters tested. This suggests suppression of recombination of the locus because of its position in the achiasmatic region of the centromere or by the total absence of meiotic recombination in these parthenogenetic females. Absence of recombination because of proximity to the centromere 
Table 3 Genotypes of five I. hastata females and their parthenogenetically produced offspring at three microsatellite loci

\begin{tabular}{llcc}
\hline $\begin{array}{l}\text { Parental } \\
\text { female }\end{array}$ & $\begin{array}{l}\text { Microsatellite } \\
\text { locus }\end{array}$ & $\begin{array}{c}\text { Parental genotype } \\
(\text { bp })\end{array}$ & $\begin{array}{c}\text { Progeny } \\
\text { genotypes }\end{array}$ \\
\hline TE1.1 & Ihas05 & $219 / 223$ & $219 / 223(20)$ \\
& Ihas08 & $191 / 193$ & $191 / 193(20)$ \\
& Ihas13 & $243 / 249$ & $243 / 249(20)$ \\
TE4.15 & Ihas05 & $219 / 223$ & $219 / 223(20)$ \\
& Ihas08 & $191 / 193$ & $191 / 193(20)$ \\
& Ihas13 & $243 / 249$ & $243 / 249(20)$ \\
TE7.4 & Ihas05 & $219 / 223$ & $219 / 223(19)$ \\
& Ihas08 & $191 / 193$ & $191 / 193(19)$ \\
& Ihas13 & $243 / 249$ & $243 / 249(20)$ \\
PI7 & & & \\
& Ihas05 & $219 / 223$ & $219 / 223(19)$ \\
& Ihas08 & $191 / 193$ & $191 / 193(19)$ \\
PI3.4 & Ihas13 & $243 / 249$ & $243 / 249(20)$ \\
& & & \\
& Ihas05 & $219 / 223$ & $219 / 223(20)$ \\
& Ihas08 & $191 / 193$ & $191 / 193(20)$ \\
\hline All & Ihas13 & $243 / 249$ & $243 / 249(17)$ \\
\hline
\end{tabular}

Alleles are indicated by their length in base pairs (bp). Numbers in parentheses indicate the number of daughters with that genotype. Note that genotypes of the mothers and their offspring are identical.

could be possible for one locus, but it is not likely for all three loci used in this case. All individuals showed the same genotype at the analysed microsatellite loci. Furthermore, a preliminary test of microsatellite loci amplification in a sample of parthenogenetic females from the Azores detected only one clone (Lorenzo Carballa et al., 2007), which suggests that recombination does not take place and that asexual populations from the Azores probably arose from a single event. Absence of recombination has been found to occur in Bdelloid rotifers (Welch and Meselson, 2000), in the parthenogenetic wasp Trichogramma cacoeciae (Vavre et al., 2004) and in parthenogenetic oribatid mites (Schaefer et al., 2006). In addition, in thelytokous females of Apis mellifera capensis, recombination rates are lower than in sexually reproducing females of the same species. In this case, thelytoky has been found to be mediated by a single Mendelian gene, although it is not known whether this gene could also be responsible for the low recombination rates observed in these parthenogenetic bees (Heimpel and de Boer, 2008).

Last, the transition from sexual reproduction to apomixis in I. hastata could have been direct, through a mutation suppressing meiosis, and thus involving major cytological changes for oogenesis (White, 1973). Further work, including cytological examination of oogenesis in parthenogenetic females, is needed to distinguish among this or any of the above-described mechanisms as the exact mechanism of parthenogenesis in I. hastata.

Populations in which tychoparthenogenesis is observed usually exhibit female-biased sex ratios (Ball, 2002). In North America, I. hastata is associated with temporary or recently established habitats, in which females are much more common that males (Belle and van Tol, 1990). In Florida, among mature populations, we recorded more females than males (Baptist

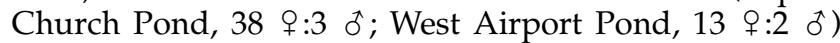
(Cordero Rivera et al., 2005).
Very little is known about the biology of sexual I. hastata. Mating is rarely observed, and probably only young mature females mate. Some authors have supposed this species to be monandric (Robinson and Allgeyer, 1996). In the laboratory, even virgin females have been observed rejecting mating, to the extent that we have never obtained a mating in captivity, which is easily obtained with other ischnurans (Lorenzo Carballa, 2009). All these biological features could make a possible tychoparthenogenetic capacity advantageous for a colonizing species like $I$. hastata in the case of geographical isolation, or when a female finds herself in a situation in which finding a mate is difficult or impossible. Thus, an important issue is to evaluate tychoparthenogenetic capacity in sexual I. hastata populations, and to investigate the biological and physical conditions under which tychoparthenogenesis would occur, to identify potential advantages of parthenogenetic reproduction (Ball, 2002).

In any case, the mechanism of parthenogenesis in $I$. hastata, being (functionally) apomictic, prevents the formation of homozygotes, and hence the expression of recessive lethal mutations, so it reduces the negative impact of the lack of sexual reproduction. In addition, the genetic fidelity of parthenogenetic reproduction relative to the recombination that accompanies sex may constitute an evolutionary advantage if the parthenogens are optimally adapted to stable environmental conditions. As the genotypes are fixed in the course of generations, there is little space for the creation of new genetic combinations, and the lack of recombination can lead to the accumulation of deleterious mutations in the population, a process known as 'Muller's Ratchet' (Muller, 1964), which has been largely considered as a strong argument against the maintenance of asexual reproduction in the long term. Increased embryo mortality has been found in parthenogenetic planarians, which possibly results from deleterious mutations (Storhas et al., 2000); nevertheless, parthenogenetic $I$. hastata females have greater fecundity and fertility than sexual ones (Lorenzo Carballa and Cordero Rivera, 2007), which suggests that the sexual females pay the twofold cost of sex through reductions in fertility rates, and this species probably supports the view that the parthenogenetic taxa can be evolutionarily successful, at least in the short term.

\section{Acknowledgements}

This research has been funded by a grant from the Spanish Ministry of Science and Culture, which included FEDER funds (CGL2005-00122). We thank the Instituto para a Conservaçao da Natureza (Lisbon) and the Secretaria Regional do Ambiente (Faial) for permits to collect damselflies in the Azores. We thank Aurore Dubuffet, Greg Hurst and John Werren for providing the positive controls for the endosymbiont detection. Thanks are also due to Christopher D. Beatty, for his comments on the manuscript and for improving the English. George Heimpel and two anonymous referees gave useful suggestions in early drafts of the paper.

\section{References}

Adachi-Hagimori T, Miura K, Stouthamer R (2008). A new cytogenetic mechanism for bacterial endosymbiont-induced 
parthenogenesis in Hymenoptera. Proc $R$ Soc Lond B 275: 2667-2673.

Arakaki N, Miyoshi T, Noda H (2001). Wolbachia-mediated parthenogenesis in the predatory thrips Franklinothrips vespiformis (Thysanoptera: Insecta). Proc R Soc Lond B Biol Sci 268: 1011-1016.

Avise JC, Quattro JM, Vrijenhoek RC (1992). Molecular clones within organisimal clones. Evol Biol 26: 225-246.

Baker MD, Vossbrinck CR, Didier ES, Maddox JV, Shadduck JA (1995). Small subunit ribosomal DNA phylogeny of various Microsporidia with emphasis on AIDS related forms. J Eukaryot Microbiol 42: 564-570.

Ball SL (2002). Population variation and ecological correlates of tychoparthenogenesis in the mayfly, Stenonema femoratum. Biol J Linn Soc 75: 101-123.

Bell G (1982). The Masterpiece of Nature: The Evolution and Genetics of Sexuality. University of California Press: Berkeley.

Belle J, van Tol J (1990). Anomalagrion hastatum (Say), an American damselfly indigenous to the Azores (Odonata, Coenagrionidae). Tijdschr Entomol 133: 143-147.

Carson HL, Chang LS, Lyttle TW (1982). Decay of female sexual behavior under parthenogenesis. Science 218: 68-70.

Cordero Rivera A, Lorenzo Carballa MO, Utzeri C, Vieira V (2005). Parthenogenetic Ischnura hastata (Say, 1839), widespread in the Azores (Zygoptera: Coenagrionidae). Odonatologica 34: 1-9.

Daly M (1978). The cost of mating. Am Nat 112: 771-774.

Dunkle SW (1990). Damselflies of Florida, Bermuda and the Bahamas, 1st edn, Scientific Publishers: Gainesville.

Fukatsu T, Nikoh N (2000). Endosymbiotic microbiota of the bamboo pseudococcid Antonina crawii. Appl Environ Microbiol 66: 643-650.

Gottlieb Y, Zchori-Fein E, Werren JH, Karr TL (2002). Diploidy restoration in Wolbachia-infected Muscidifurax uniraptor (Hymenoptera: Pteromalidae). J Invertebr Pathol 81: 166-174.

Heimpel GE, de Boer JG (2008). Sex determination in the Hymenoptera. Ann Rev Entomol 53: 209-230.

Hagimori T, Abe Y, Date S, Miura K (2006). The first finding of a Rickettsia bacterium associated with parthenogenesis induction among insects. Curr Microbiol 52: 97-101.

Jeyaprakash A, Hoy MA (2000). Long PCR improves Wolbachia DNA amplification: wsp sequences found in $76 \%$ of sixty-three arthropod species. Insect Mol Biol 9: 393-405.

Kato H, Watanabe Y, Yokota H (1997). Preliminary note on artificial parthenogenesis in Stylurus oculatus (Odonata, Gomphidae). New Entomol 46: 16-19.

Kiauta B (1969a). Autosomal fragmentations and fusions in Odonata and their evolutionary implications. Genetica 40: 158-180.

Kiauta B (1969b). Sex chromosomes and sex determining mechanisms in Odonata, with a review of the cytological conditions in the family Gomphidae, and references to the karyotypic evolution in the order. Genetica 40: 127-157.

Kondrashov AS (1993). Classification of hypotheses on the advantage of amphimixis. J Hered 84: 372-387.

Kramer MG, Templeton AR (2001). Life-history changes that accompany the transition from sexual to parthenogenetic reproduction in Drosophila mercatorum. Evolution 55: 748-761.

Lorenzo Carballa MO (2009). Reproduction without sex: the case of the damselfly $I$. hastata in the Azores islands. PhD dissertation. Universidade de Vigo.

Lorenzo Carballa MO, Cordero Rivera A (2007). Are parthenogenetic and sexual Ischnura hastata damselflies equally fertile? Testing sexual conflict theories. Ethol Ecol Evol 19: 291-298.

Lorenzo Carballa MO, Cordero Rivera A, Giere S, Hadrys H (2007). Isolation and characterization of microsatellite loci to study parthenogenesis in the citrine forktail, Ischnura hastata. Mol Ecol Notes 7: 839-841.
Lynch M (1984). Destabilizing hybridization, general-purpose genotypes and geographic parthenogenesis. Q Rev Biol 59: 257-290.

Mateos M, Castrezana SJ, Nankivell BJ, Estes AM, Markow TA, Moran NA (2006). Heritable endosymbionts of Drosophila. Genetics 174: 363-376.

Maynard-Smith J (1978). The Evolution of Sex. Cambridge University Press: Cambridge.

Mola LM (1995). Post-reductional meiosis in Aeshna (Aeshnidae, Odonata). Hereditas 122: 47-55.

Muller HJ (1964). The relation of recombination to mutational advance. Mutat Res 1: 2-9.

Pannebakker BA, Pijnacker LP, Zwaan BJ, Beukeboom LW (2004). Cytology of Wolbachia-induced parthenogenesis in Leptopilina clavipes (Hymenoptera:Figitidae). Genome 47: 299-303.

Provencher LM, Morse GE, Weeks AR, Normark BB (2005). Parthenogenesis in the Aspidiotus nerii complex (Hemiptera: Diaspididae): a single origin of a worldwide, ployphagous lineage associated with Cardinium bacteria. Ann Entomol Soc Am 98: 629-635.

Reed DL, Hafner MS (2002). Phylogenetic analysis of bacterial communities associated with ectoparasitic chewing lice of pocket gophers: a culture-independent approach. Microb Ecol 44: 78-93.

Robinson JV, Allgeyer R (1996). Covariation in life-history traits, demographics and behaviour in ischnuran damselflies: the evolution of monandry. Biol J Linn Soc 58: 85-98.

Schaefer I, Domes K, Heethoff M, Schneider K, Schon I, Norton RA et al. (2006). No evidence for the 'Meselson effect' in parthenogenetic oribatid mites (Oribatida, Acari). J Evol Biol 19: 184-193.

Schwander T, Crespi BJ (2009). Multiple direct transitions from sexual reproduction to apomictic parthenogenesis in Timema walking sticks. Evolution 63: 84-103.

Simon J-C, Delmotte F, Rispe C, Crease T (2003). Phylogenetic relationships between parthenogens and their sexual relatives: the possible routes to parthenogenesis in animals. Biol J Linn Soc 79: 151-163.

Storhas M, Weinzierl MRP, Michiels NK (2000). Paternal sex in parthenogenetic planarians: a tool to investigate the accumulation of deleterious mutations. J Evol Biol 13: 1-8.

Stouthamer R, Breeuwert JA, Luck RF, Werren JH (1993). Molecular identification of microorganisms associated with parthenogenesis. Nature 361: 66-68.

Stouthamer R, Kazmer DJ (1994). Cytogenetics of microbeassociated parthenogenesis and its consequences for gene flow in Trichogramma wasps. Heredity 73: 317-327.

Stouthamer R, Werren JH (1993). Microbes associated with parthenogenesis in wasps of the genus Trichogramma. J Invertebr Pathol 61: 6-9.

Suomalainen E, Saura A, Lokki J (1987). Cytology and Evolution in Parthenogenesis. CRC Press: Boca Raton, Florida.

Templeton AR (1982). The prophecies of parthenogenesis. In: Dingle $\mathrm{H}$, Hegmann JP (eds). Evolution and Genetics of Life Histories. Springer-Verlag: New York, pp 75-101.

Thao ML, Baumann P (2004). Evidence for multiple acquisition of Arsenophonus by whitefly species (Sternorrhyncha: Aleyrodidae). Curr Microbiol 48: 140-144.

Thipaksorn A, Jamnongluk W, Kittayapong P (2003). Molecular evidence of Wolbachia infection in natural populations of tropical odonates. Curr Microbiol 47: 314-318.

Vandekerckhove TTM, Willems A, Gillis M, Coomans A (2000). Occurrence of novel verrucomicrobial species, endosymbiotic and associated with parthenogenesis in Xiphinema americanum-group species (Nematoda, Longidoridae). Int J Syst Evol Microbiol 50: 2197-2205.

Vandel A (1928). La Parthénogenèse géographique: contribution à l'étude biologique et cytologique de la parthénogenèse naturelle. Bull Biol Fr Bel 62: 164-281. 
Vavre F, de Jong JH, Stouthamer R (2004). Genetic mechanism and genetic consequences of thelytoky in the wasp Trichogramma cacoeciae. Heredity 93: 592-596.

Watanabe Y, Yokota H, Kato H, Hatakeyama M (1999). Artificial parthenogenesis in the dragonfly, Stylurus oculatus (Odonata). Proc Arthropod Embryol Soc Jpn 34: 31-32.

Weeks AR, Breeuwer JAJ (2001). Wolbachia-induced parthenogenesis in a genus of phytophagous mites. Proc $R$ Soc Lond $B$ Biol Sci 268: 2245-2251.

Weeks AR, Velten R, Stouthamer R (2003). Incidence of a new sex-ratio-distorting endosymbiotic bacterium among arthropods. Proc R Soc Lond B Biol Sci 270: 1857-1865.

Weisburg WG, Barns S, Pelletier DA, Lane DJ (1991). 16S ribosomal DNA amplification for phylogenetic study. J Bacteriol 173: 697-703.

Welch DM, Meselson M (2000). Evidence for the evolution of bdelloid rotifers without sexual reproduction or genetic exchange. Science 288: 1211-1215.

Wenseleers T, Billen J (2000). No evidence for Wolbachia induced parthenogenesis in the social Hymenoptera. J Evol Biol 13: 277-280.

Werren JH (1997). Biology of Wolbachia. Ann Rev Entomol 42: 587-609.
Werren JH, Windsor DM (2000). Wolbachia infection frequencies in insects: evidence of a global equilibrium? Proc $R$ Soc Lond B: Biol Sci 267: 1277-1285.

West SA, Lively CM, Read AF (1999). Sex may need more than one. J Evol Biol 12: 1053-1055.

White MJD (1973). Animal Cytology and Evolution. Cambridge University Press: Cambridge.

Williams GC (1966). Adaptation and Natural Selection. Princeton University Press: Princeton.

Williams GC (1975). Sex and Evolution. Princeton University Press: Princeton.

Zchori-Fein E, Gottlieb Y, Kelly SE, Brown JK, Wilson JM, Karr TL et al. (2001). A newly discovered bacterium associated with parthenogenesis and change in host selection behavior in parasitoid wasps. Proc Nat Acad Sci USA 98: 12555-12560.

Zchori-Fein E, Perlman SJ (2004). Distribution of the bacterial symbiont Cardinium in arthropods. Mol Ecol 13: 2009-2016.

Zchori-Fein E, Perlman SJ, Kelly SE, Katzir N, Hunter MS (2004). Characterization of a 'Bacteroidetes' symbiont in Encarsia wasps (Hymenoptera : Aphelinidae): proposal of 'Candidatus Cardinium hertigii'. Int J Syst Evol Microbiol 54: 961-968. 